\title{
Taxonomic Diversity Hidden Inside the Mantle of Octopus Vulgaris: Valuable Source of Information
}

\author{
Alba Jurado-Ruzafa ${ }^{1} \cdot$ Verónica Duque-Nogal $^{2} \cdot$ M. Nazaret Carrasco ${ }^{1} \cdot$ Marcos González-Porto $^{1}$. \\ José González-Jiménez ${ }^{1}$. Víctor M. Tuset ${ }^{3,4}$ (1)
}

Received: 20 August 2021 / Revised: 6 October 2021 / Accepted: 28 October 2021

(c) The Author(s), under exclusive licence to Springer Nature Switzerland AG 2021

\begin{abstract}
The common octopus, Octopus vulgaris, is a very important demersal fishery resource targeted, among other fleets, by freezer bottom-trawlers in the Mauritanian Economic Exclusive Zone (MEEZ). From August 2010 to September 2011, a total of 1696 octopuses caught in the MEEZ where analysed. Many organisms trapped into the octopuses' mantle were found and identified, which are jointly swept while the trawling catches the targeted species. A latitudinal (by ecoregion) and depth study was performed to determine differences in the taxonomic diversity of these hidden organisms. The findings showed that the diversity patterns were similar to already established in the area based on scientific surveys. Therefore, this ignored bycatch could provide complementary ecological information of the habitat of $O$. vulgaris.
\end{abstract}

Keywords Octopus $\cdot$ Bottom trawl $\cdot$ Species richness $\cdot$ Spatial distribution $\cdot$ Mauritanian waters

\section{Introduction}

The common octopus Octopus vulgaris (Cuvier 1797) inhabits a wide spectrum of benthic substrates (e.g., rocky bottoms, reefs, grass beds and soft sediments) from coastal to outer shelf worldwide (Jouffre 1998; Sauer et al. 2019). This species is a very important demersal fishing resource around the world, supporting artisanal and industrial fisheries (Roper et al. 1984; Xavier et al. 2015). Its ecological adaptability is also reflected in the diverse fishing gears used for its capture (e.g., lures, hooks and lines, pots and spears), although the bottom trawling is often the most relevant in

Víctor M. Tuset

vtuset@ulpgc.es

1 Instituto Español de Oceanografía (IEO-CSIC), Centro Oceanográfico de Canarias. Vía Espaldón, Dársena Pesquera (38180), Santa Cruz de Tenerife, Spain

2 Instituto Español de Oceanografía (IEO-CSIC), Centro Oceanográfico de Cádiz. Muelle de Levante, Puerto Pesquero (11006), Cádiz, Spain

3 Instituto de Oceanografía y Cambio Global (IOCAG), Universidad de Las Palmas de Gran Canaria, Campus de Taliarte, 35214 Telde, Gran Canaria, Spain

4 Institut de Ciències del Mar (ICM-CSIC), Passeig Marítim de la Barceloneta, 37-49, 08003 Barcelona, Spain landings (Roper et al. 1984; Sauer et al. 2019). One of the most important bottom trawl fisheries in the world targeting cephalopods occurs in the Northwest African waters, from the Saharan Bank to Senegal (e.g., Sobrino and García 1992; Balguerías et al. 2000; Sauer et al. 2019). This region is enriched by the Canary Current Upwelling System, one of the four main eastern boundary upwelling ecosystems in the world, where a variable year-round upwelling occurs (Demarcq and Faure 2000; Arístegui et al. 2009; Klenz et al. 2018).

The Mauritanian Exclusive Economic Zone (MEEZ) has been exploited by a great variety of foreign fleets, being the most important fishing grounds for Spanish cephalopod-targeted freezer trawlers since the mid XX century. It has changed only in the first decade of the XXI century, when the sustainable fisheries partnership agreement (SFPA) between Mauritania and the European Union was modified (Council Decision, of 18 December 2012, Official Journal of the European Union, number 2012/827/EU). Due to its commercial and ecological importance, numerous studies have addressed the fisheries, biology and population dynamic of the common octopus (e.g., Balguerías et al. 2002; Murphy et al. 2002; Perales-Raya et al. 2010, 2014; Jurado-Ruzafa et al. 2014). But surprisingly, only one study has estimated the overall bycatch of this fishing activity in the MEEZ 
(Vázquez-Rowe et al. 2012) and another one, its impact on benthic ecosystems (Atkinson et al. 2011). The absence of reliable time series of catches of $O$. vulgaris in the region, its overfishing and the risk of irreversible stock depletion are worrisome (Sauer et al. 2019). In addition, although to count discards is mandatory to achieve a reliable assessment of any fishing activity (Alverson et al. 1994), it is still a pending issue in the region. Due to scientific observers onboard were not allowed in the past, an intense sampling program was designed for the fishery in MEEZ by the Centro Oceanográfico de Canarias del Instituto Español de Oceanografía-Centro Superior de Investigaciones Científicas (COC of IEO-CSIC) between August 2010 to September 2011, in the framework of a collaborative project with ANACEF ("Asociación Nacional de Armadores de Buques Congeladores de Pesca de Cefalópodos"), whose associated cephalopod-targeted freezer trawlers operated in the Mauritanian waters. During this project, commercial landings were analyzed by researchers who highlighted the presence of numerous organisms swept jointly and 'trapped' into the octopuses' mantle (Supplementary Information Fig. SI1). In this context, in the absence of information on discards for commercial fleet activity, a question raised up: could these organisms trapped into the octopuses' mantles describe or give information about the taxonomic diversity in the region? Trawling samplings are considered an essential step for extrapolating information from benthic samples to the larger scale of habitats (de Juan et al. 2013). In fact, many specific scientific surveys have addressed the study of benthonic assemblages along the Mauritanian coast and shelf (Le Lœuff and von Cosel 1998; Jouffre and Inejih 2005; Gascuel et al. 2007), which finally have entailed an additional trawling impact on the bottom to the impact performed by commercial fisheries (Sauer et al. 2019).

Indirect approaches to describe the ecosystem taxonomical diversity using stomach content analyses have been used in the Atlantic Moroccan bottoms (Abdellaoui et al. 2017), according to literature (e.g., Cherel et al. 2004; Lansdell and Young 2007). Knowing that they do not represent the true diversity of ecosystems and that the information on the status of this fishing ground is scarce, their seasonal and geographical variation may serve as tool to detect disturbances in the region, supporting management recommendations where the collaboration of cephalopod-targeted freezer trawlers would play a role. The main goal of present study was (i) to determine the species found within the octopuses' mantle, and (ii) to test if the taxonomic diversity found follow the same pattern of spatial pattern (latitude and depth) described in the MEEZ and driving by upwelling phenomena and the seasonal displacements of thermal fronts (Jager 1993; Le Lœuff and von Cosel 1998; Demarcq and Faure 2000; Arístegui et al. 2009).

\section{Materials and Methods}

The sample collection strategy (by vessel) designed for the mentioned collaborative project consisted of picking weekly one octopus of each commercial weight category, when possible, based on the commercial classification by Mitzubishi (see Jouffre et al. 2000). A total of $2622 O$. vulgaris were analyzed from August 2010 to September 2011. Data used here correspond to the 1696 octopuses which contained some trapped organism/s in the mantle, varying from 129.2 to $6961.2 \mathrm{~g}$ of total weight. The midpoint of the positions registered for the 212 hauls in which each of them were caught has been used as a georeference proxy (Supplementary Information Fig. SI2). The mantletrapped organisms were extracted, photographed, labelled, and conserved frozen to be examined later. Every organism was identified to the lowest taxonomic level possible and crossed with data of the octopuses in whose mantles were found.

Depth information was assigned based on the provided coordinates by vessels and three strata were considered (Duineveld et al. 1993): shallow ( $<50 \mathrm{~m})$, medium (50$100 \mathrm{~m}$ ) and deep (>100 m). Besides, samples were also grouped in three latitudinal ecoregions (Gascuel et al. 2007; Kidé et al. 2015): northern $\left(>19^{\circ} 15^{\prime} \mathrm{N}\right)$, central $\left(19^{\circ} 15^{\prime} \mathrm{N}-17^{\circ} 40^{\prime} \mathrm{N}\right)$ and southern $\left(<17^{\circ} 40^{\prime} \mathrm{N}\right)$. Matrix information on the presence/absence of species by zone (depth strata and ecoregions) is presented in Supplementary Information Table SI1.

The species richness was expressed as the total number of species found into the octopuses' mantle in each zone. Two taxonomic diversity measures were estimated based on distance between each pair of individuals as defined by a Linnaean classification tree (Warwick and Clarke 1995; Clarke and Warwick 2001): average taxonomic distinctness (AvTD or $\Delta^{+}$) and variation in taxonomic distinctness (VarTD or $\Lambda^{+}$). The average taxonomic distinctness defined the mean number of steps up the hierarchy that must be taken to reach a taxonomic rank common to two species, computed across all possible pairs of species:

$\Delta^{+}=\left[\sum \sum_{i<j} \omega_{i j}\right] /[S(S-2) / 2]$

where $\omega$ is the branch length between species pairs and $S$ is the number of observed species in the sample. The variation in taxonomic distinctness reflects the degree to which certain taxonomic groups are over- or underrepresented in one sample. This index can help distinguish between taxonomic trees that may have the same number of species but an unequal structure tree, considering taxonomic units: 
Fig. 1 Megafaunal species trapped into octopuses' mantle analysed in the Mauritanian waters. a invertebrates; $\mathbf{b}$ fishes
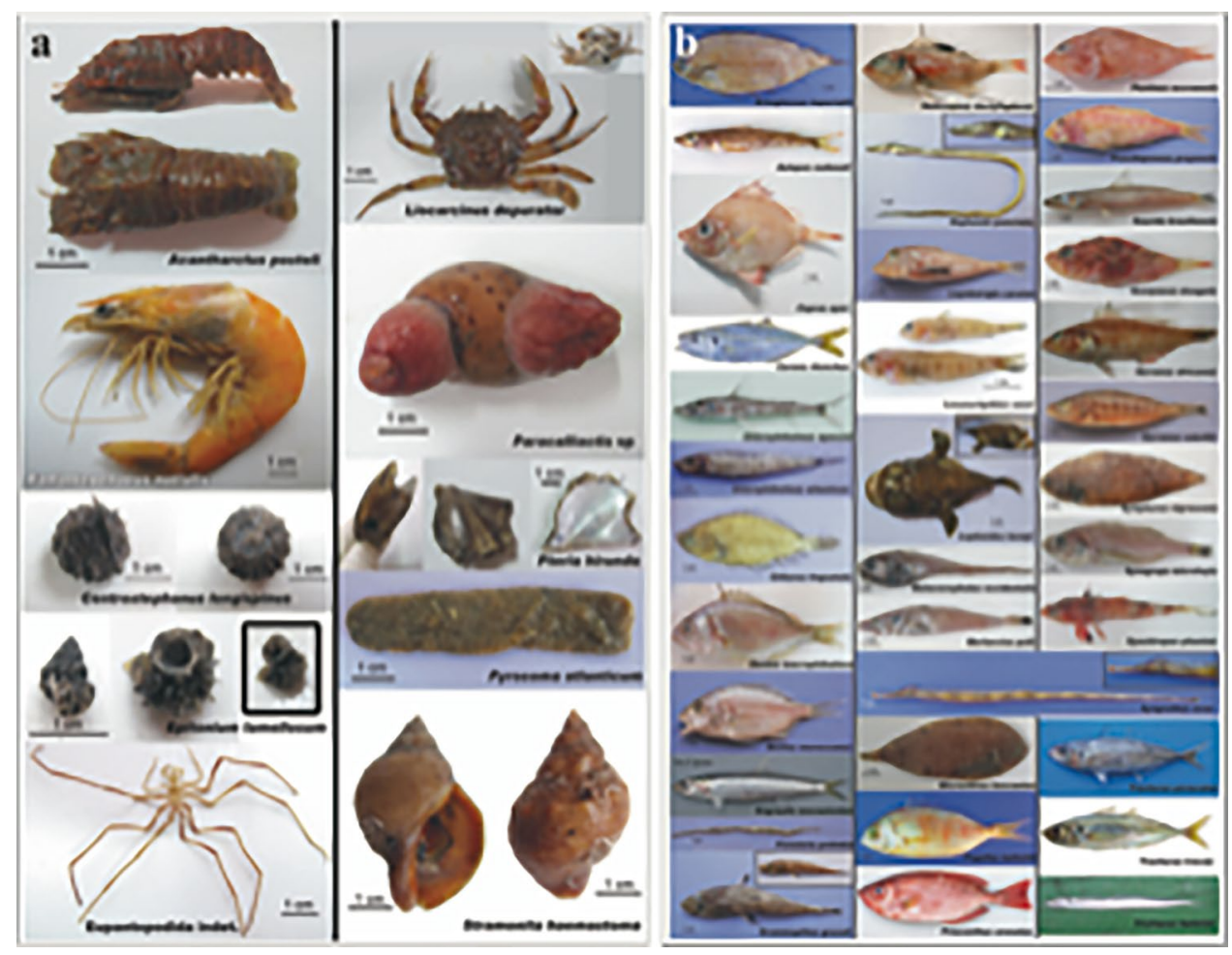

Fig. 2 Phylum importance by ecoregion and depth of megafaunal trapped into octopuses' mantle analysed in the Mauritanian waters

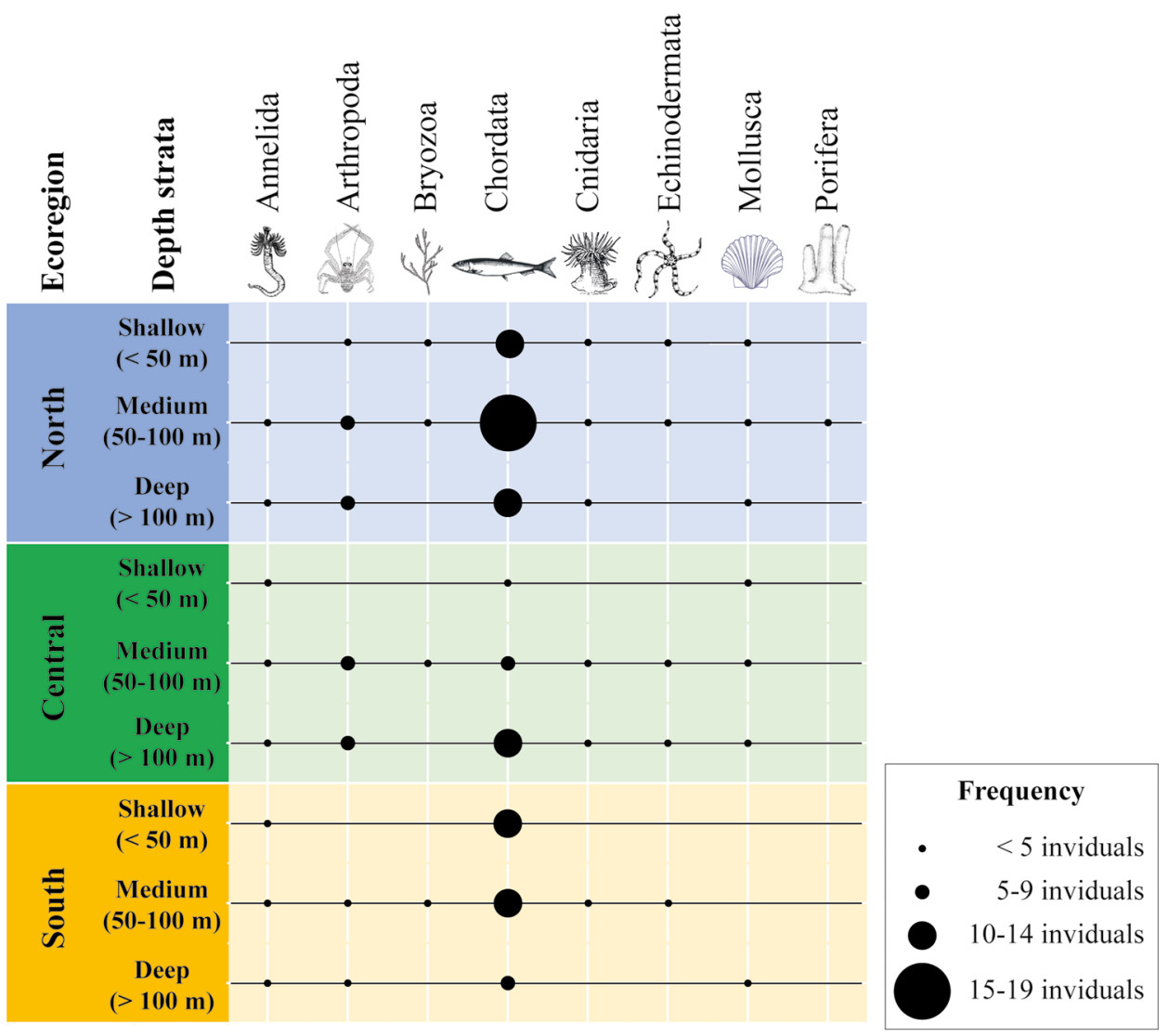


Table 1 Taxonomic diversity trapped into the octopuses' mantle in the Mauritania waters. S, species richness; AvTD, average taxonomic distinctness $(\Delta+)$; VarTD, variation in taxonomic distinctness $(\Lambda+)$

\begin{tabular}{lllrr}
\hline Ecoregion & Depth & $S$ & AvTD & VarTD \\
\hline Northern & Shallow & 21 & 78.00 & 4.14 \\
& Medium & 34 & 81.08 & 2.47 \\
& Depth & 19 & 77.20 & 3.83 \\
Central & Shallow & 3 & 100.00 & 17.16 \\
& Medium & 21 & 85.05 & 3.83 \\
& Depth & 21 & 84.28 & 3.83 \\
Southern & Shallow & 13 & 55.00 & 6.19 \\
Southern & Medium & 22 & 80.18 & 3.68 \\
& Depth & 13 & 77.81 & 5.49 \\
\hline
\end{tabular}

$\Lambda^{+}=\left[\sum \sum_{i<j}\left(\omega_{i j}-\Delta^{+}\right)^{2}\right] /[S(S-2) / 2]$

where $\omega$ is the branch length between species pairs and $S$ is the number of observed species in the sample and $\Delta+$ is the average taxonomic distinctness for the sample as defined above. The taxonomic hierarchies used in this study were species, genus, family, order, class and phylum.

In order to check if the taxonomic diversity follows a similar spatial distribution pattern as described in the literature, pairwise similarity matrices using Jaccard's index were computed and a dendrogram was obtained to visualize them (Warwick and Clarke 1995; Clarke and Warwick 2001). All statistical analyses were performed in R statistical and computing environment ( $\mathrm{R}$ Core Team 2020).

\section{Results and Discussion}

A total of 66 species present into the mantles of octopuses were identified and classified into eight phyla (Fig. 1, Supplementary Information Table SI1). The phylum Chordata (mainly Osteichthyes) and Arthropoda (mainly Decapoda) were the most common taxonomic groups in the three ecoregions and depth strata considered in the present study, although other phyla acquired a higher prevalence depending on ecoregion: Cnidaria in the northern, Annelida and Mollusca in the central and Annelida in the southern (Fig. 2). Five species of Osteichthyes were reiteratively found into mantles: Arnoglossus imperialis (Bothidae), Microchirus boscanion (Soleidae), Helicolenus dactylopterus (Sebastidae) and Dentex macrophthalmus (Sparidae) characterized by a benthic life-style, and Capros aper (Caproidae) with a benthopelagic behaviour (Supplementary Information Table SI1). In general, $H$. dactylopterus and $P$. heterocarpus only appeared in the northern ecoregion and $M$. boscanion was only sampled in the southern ecoregion. Including depth strata, fish species were mainly found in the medium strata (50-100 $\mathrm{m})$ in the northern and in the deep strata in the central zone, whereas in the southern zone was similar observed in all strata (Supplementary Information Table SI1). Two Decapoda (Munida cf. iris and Plesionika heterocarpus) were commonly collected too.

The highest species richness $(n=34)$ was noted in the northern ecoregion between 50 and $100 \mathrm{~m}$ of depth, and the lowest ones $(n=3)$, in samples from the central ecoregion at depth $>100 \mathrm{~m}$ (Table 1). Simulation test on $\Delta^{+}$using funnels showed that sites' values generally fell within the $95 \%$
Fig. 3 Average taxonomic distinctness $\left(\Delta^{+}\right)$against numbers of species trapped' into the octopuses' mantle in the Mauritania waters in relation to the "expected" value (and its upper and lower $95 \%$ probability limits) of this index. Color dot indicates the ecoregion: blue - northern; green - central; yellow - southern

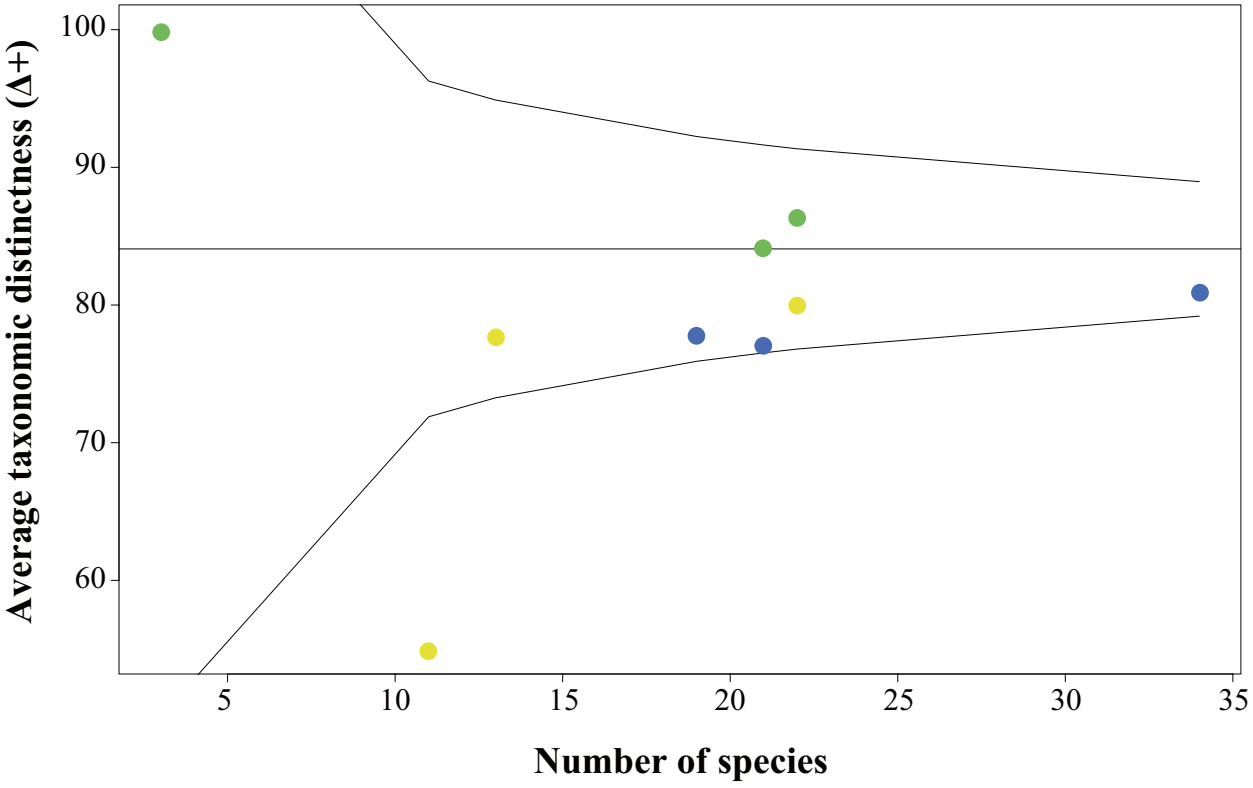




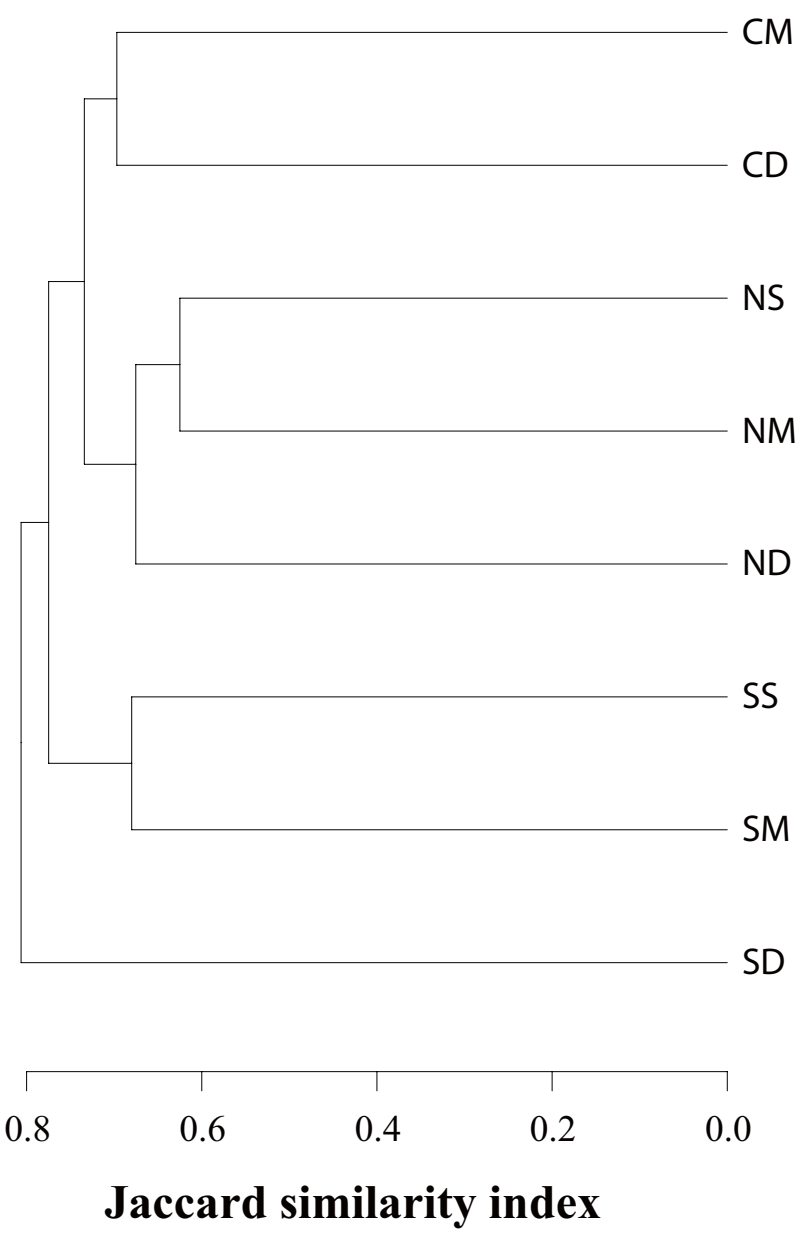

Fig. 4 Dendrogram of the cluster analysis of the species trapped' into the octopuses' mantle in the Mauritania waters (Jaccard similarity index). CD - central ecoregion and deep stratum; CM - central ecoregion and medium stratum; ND - northern ecoregion and deep stratum; NM - northern ecoregion and medium stratum; NS - northern ecoregion and shallow stratum; SD - southern ecoregion and deep stratum; NM - southern ecoregion and medium stratum; NS southern ecoregion and shallow stratum

confidence funnel, and only one case (southern ecoregion at $>100 \mathrm{~m}$ of depth) was lower than the expected mean (Fig. 3). The highest values of $\Delta^{+}$were reached in the central ecoregion, while the highest values of $\Lambda^{+}$were observed in the southern ecoregion (Table 1). These findings agreed with the idea that the diversity in the shallow Mauritanian waters follows a spatial gradient (latitudinal and bathymetric) promoted by the favourable environmental conditions (Jager 1993; Demarcq and Faure 2000; Kidé et al. 2015). A permanent upwelling occurs in the northern ecoregion, while it is seasonal (from December to March) in the central ecoregion (Le Loeuff and von Cosel 1998; Arístegui et al. 2009). The presence of processes provides higher plankton productivity supporting a large variety of fish communities (Hagen 2001; Zeeberg et al. 2006; Kidé et al. 2015). That is reflected in the cluster obtained, where a clear latitudinal separation was noted (Fig. 4). On another hand, the MEEZ is considered a transitional zone between temperate and tropical marine fauna (Le Loeuff and von Cosel 1998; García-Isarch et al. 2017), which may explain the high taxonomic diversity found in the three ecoregions. Finally, the type of bottom (soft vs. rocky) between shallow and medium strata also seemed to influence $\Delta^{+}$, being higher in rocky bottoms, as occurs in other geographical regions (Tuya et al. 2019).

In conclusion, despite the limitations assumed in the present study (mainly in terms of quantitative-based results), our findings followed the expected diversity pattern in the study area. Cephalopod-targeted fisheries occurs worldwide (Sauer et al. 2019), but scientific observations onboard are still scarce, and discards are poorly studied or not reported at all. The analyzed hidden organisms are not even considered discards and at present this information is lost. Based on the present results, the consideration and sampling of these hidden specimens within the mantle of the commercially caught octopuses (and/or other cephalopods) may provide valuable indirect information about the ecosystems where octopuses inhabit. This indirect information-source may be considered complementary to the high-cost scientific surveys.

Supplementary Information The online version contains supplementary material available at https://doi.org/10.1007/s41208-021-00373-6.

Acknowledgements Authors want to thank to Octavio Melián, the fleet captains and crews (ANACEF) for selecting the octopuses' samples. Specially thanks to our IEO-colleagues Carlos Hernández-González and Eva Hernández for helping with the reception and transport of these samples to the laboratory.

Author Contributions AJR conceived the study, conducted the sampling and wrote the paper; VDN, MNC, MGP and JGJ carried out the sampling and the identification of marine organisms; VMT performed the statistical analysis and wrote the manuscript. All authors commented on previous versions of the manuscript and approved the final manuscript.

Funding Information This project was partially funded by the EU through the European Maritime and Fisheries Fund (EMFF) within the Spanish National Program of collection, management and use of data in the fisheries sector and support for scientific advice regarding the Common Fisheries Policy.

\section{Declarations}

Ethics Approval All applicable international, national, and/or institutional guidelines for the care and use of animals were followed by the authors.

Consent to Participate All necessary permits for sampling and observational field studies have been obtained by the authors from the competent authorities and are mentioned in the acknowledgements, if applicable. 
Consent for Publication The datasets generated during and/or analysed during the current study are available in the Table SI1 of Electronic Supplementary Information.

Conflicts of Interest/Competing Interests The authors declare that they have no conflict of interest.

\section{References}

Abdellaoui S, El Halouani H, Tai I, Masski H (2017) Resource partitioning within major bottom fish species in a highly productive upwelling ecosystem. J Mar Syst 173:1-8. https://doi.org/10. 1016/j.jmarsys.2017.03.012

Alverson DL, Freeberg MH, Pope JG, Murawski SA (1994) A global assessment of fisheries bycatch and discards. FAO Fish Tech Pap 339:1-233

Arístegui J, Barton ED, Álvarez-Salgado XA, Santos AMP, Figueiras FG, Kifani S, Hernández-León S, Mason E, Machú E, Demarcq H (2009) Sub-regional ecosystem variability in the Canary Current upwelling. Progr Oceanogr 83:33-48. https://doi.org/10. 1016/j.pocean.2009.07.031

Atkinson LJ, Field JG, Hutchings L (2011) Effects of demersal trawling along the west coast of southern Africa: multivariate analysis of benthic assemblages. Mar Ecol Progr Ser 430:241-255. https://doi.org/10.3354/meps08956

Balguerías E, Hernández-González CL, Perales-Raya C (2002) On the identity of Octopus vulgaris Cuvier, 1797 stocks in the Saharan Bank (Northwest Africa) and their spatio-temporal variations in abundance in relation to some environmental factors. Bull Mar Sci 71:147-163

Balguerías E, Quintero ME, Hernández-González CL (2000) The origin of the Saharan Bank cephalopod fishery. ICES J Mar Sci 57:15-23. https://doi.org/10.1006/jmsc.1999.0572

Clarke KR, Warwick RM (2001) A further biodiversity index applicable to species lists, variation in taxonomic distinctness. Mar Ecol Progr Ser 216:265-278. https://doi.org/10. 3354/meps 216265

Cherel Y, Duhamel G, Gasco N (2004) Cephalopod fauna of subantarctic islands: new information from predators. Mar Ecol Progr Ser 266:143-156. https://doi.org/10.3354/meps266143

de Juan S, Iacono CL, Demestre M (2013) Benthic habitat characterisation of soft-bottom continental shelves: Integration of acoustic surveys, benthic samples and trawling disturbance intensity. Estuar Coast Shelf Sci 117:199-209. https://doi.org/10.1016/j. ecss.2012.11.012

Demarcq H, Faure V (2000) Coastal upwelling and associated retention indices derived from satellite SST. Application to Octopus vulgaris recruitment. Oceanol Acta 23:391-408. https://doi.org/ 10.1016/S0399-1784(00)01113-0

Duineveld GCA, Lavaleye MSS, Noort GJ (1993) The trawlfauna of the Mauritanian shelf (Northwest Africa): density, species composition, and biomass. Hydrobiologia 258:165-173. https:// doi.org/10.1007/978-94-011-1986-3_14

García-Isarch E, de Matos-Pita SS, Muñoz I, Mohamed Moctar SM, Ramil F (2017) Decapod Assemblages in Mauritanian Waters. In: Ramos A, Ramil F, Sanz JL (eds) Deep-Sea Ecosystems Off Mauritania: Research of Marine Biodiversity and Habitats in the Northwest African Margin. Dordrecht. Springer, Netherlands, pp 355-391

Gascuel D, Labrosse P, Meissa B, Taleb Sidi MO, Guénette S (2007) Decline of demersal resources in North-West Africa: an analysis of Mauritanian trawl-survey data over the past 25 years. Afr J Mar Sci 29:331-345. https://doi.org/10.2989/AJMS.2007.29.3.3.333
Hagen E (2001) Northwest African upwelling scenario. Oceanol Acta 24:112-113

Jager Z (1993) The distribution and abundance of young fish in the Banc d'Arguin, Mauritania. Hydrobiologia 258:185-196. https://doi.org/10.1007/BF00006196

Jouffre D (1998) Octopus vulgaris as a component of the benthic fauna of the NW African coast: A note on an investigation of species community organization using multifactorial analysis. South Afr J Mar Sci 20:93-100. https://doi.org/10.2989/ 025776198784126449

Jouffre D, Inejih CA, Simier M (2000) Cycle biologique du poulpe (Octopus vulgaris) au large du Cap-Blanc (Mauritanie). In: Gascuel D, Chavance P, Bez N, Biseau A (eds) Les espaces de l'halieutique. Paris. Éditions IRD, pp 243-267

Jouffre D, Inejih CA (2005) Assessing the impact of fisheries on demersal fish assemblages of the Mauritanian continental shelf, 1987-1999, using dominance curves. ICES J Mar Sci 62:380 383. https://doi.org/10.1016/j.icesjms.2004.11.007

Jurado-Ruzafa A, Duque V, Carrasco MN (2014) Reproductive aspects of Octopus vulgaris, Cuvier 1797 (Cephalopoda: Octopodidae), caught in Mauritanian waters by the industrial Spanish fleet (NW Africa). Vieraea 42:149-164

Kidé SO, Manté C, Dubroca L, Demarcq H, Mérigot B (2015) Spatio-temporal dynamics of exploited groundfish species assemblages faced to environmental and fishing forcings: insights from the Mauritanian Exclusive Economic Zone. PLoS One 10:e014156. https://doi.org/10.1371/journal.pone.0141566

Klenz T, Dengler M, Brandt P (2018) Seasonal variability of the mauritania current and hydrography at $18^{\circ} \mathrm{N}$. J Geophys Res Oceans 123:8122-8137. https://doi.org/10.1029/2018JC014264

Lansdell M, Young J (2007) Pelagic cephalopods from eastern Australia: species composition, horizontal and vertical distribution determined from the diets of pelagic fishes. Rev Fish Biol Fish 17(2):125-138. https://doi.org/10.1007/s11160-006-9024-8

Le Lœuff P, von Cosel R (1998) Biodiversity patterns of the marine benthic fauna on the Atlantic coast of tropical Africa in relation to hydroclimatic conditions and paleogeographic events. Acta Oecol 19:309-321. https://doi.org/10.1016/S1146-609X(98)80035-0

Murphy JM, Balguerías E, Key LN, Boyle PR (2002) Microsatellite DNA markers discriminate between two Octopus vulgaris (Cephalopoda: Octopoda) fisheries along the northwest African coast. Bull Mar Sci 71:545-555

Perales-Raya C, Bartolomé A, García-Santamaría MT, PascualAlayón P, Almansa E (2010) Age estimation obtained from analysis of octopus (Octopus vulgaris Cuvier, 1797) beaks: Improvements and comparisons. Fish Res 106:171-176. https:// doi.org/10.1016/j.fishres.2010.05.003

Perales-Raya C, Jurado-Ruzafa A, Bartolomé A, Duque V, Carrasco MN, Fraile-Nuez E (2014) Age of spent Octopus vulgaris and stress mark analysis using beaks of wild individuals. Hydrobiologia 725:105-114. https://doi.org/10.1007/S10750-013-1602-X

R Core Team (2020) R: A language and environment for statistical computing. R Foundation for Statistical Computing, Vienna, Austria. URL https://www.R-project.org/

Roper CFE, Sweeney MJ, Nauen CE (eds) (eds 1984) FAO species catalogue. Cephalopods of the world. An annotated and illustrated catalogue of species of interest to fisheries. FAO Fish Synop 125:1-277

Sauer WH, Gleadall IG, Downey-Breedt N, Doubleday Z, Gillespie G, Haimovici M, Ibañez CM, Katugin ON, Leporati S, Lipinski M, Markaida U, Ramos JE, Rosa R, Villanueva R, Arguelles J, Briceño FA, Carrasco SA, Che LJ, Chen CS, Cisneros R, Conners E, Crespi-Abril A, Kulik VV, Drobyazin EN, Emery TJ, Fernandez-Alvarez FA, Furuya H, Gonzalez LW, Gough C, Krishnan P, Kumar B, Leite T, Lu CC, Mohamed KS, Nabhitabhata J, Noro K, Petchkamnerd J, Putra D, Rocliffe S, Sajikumar KK, Sakaguchi H, Samuel D, Sasikumar G, Wada 
T, Zheng X, Tian Y, Pang Y, Yamrungrueng A (2019) World Octopus Fisheries. Rev Fish Sci Aqua

Sobrino I, García T (1992) Análisis y descripción de la actividad de la flota española en las pesquerías de crustáceos decápodos profundos en aguas de la República de Senegal durante el periodo 1987-1990. Inf téc Inst Español Oceanogr 125:1-37

Tuya F, Asensio M, Bosch NE, García A, Navarro A (2019) Partitioning multiple diversity dimensions of nearshore fish assemblages within a coastal seascape. Hydrobiologia 834:87-102. https://doi.org/10.1007/s10750-019-3911-1

Vázquez-Rowe I, Moreira MT, Feijoo G (2012) Environmental assessment of frozen common octopus (Octopus vulgaris) captured by Spanish fishing vessels in the Mauritanian EEZ. Mar Policy 36:180-188. https://doi.org/10.1016/j.marpol.2011.05. 002
Warwick RM, Clarke KR (1995) New 'biodiversity' measures reveal decrease in taxonomic distinctness with increasing stress. Mar Ecol Prog Ser 129:301-305. https://doi.org/10. 3354/meps 129301

Xavier JC, Allcock Al, Cherel Y, Lipinski MR, Pierce GJ, Rodhouse PGK, Rosa R, Shea EK, Strugnell JM, Vidal EAG, Villanueva R, Ziegler A (2015) Future challenges in cephalopod research. J Mar Biol Assoc UK 95:999-1015. https://doi.org/10.1017/ S0025315414000782

Zeeberg J, Corten A, de Graaf E (2006) Bycatch and release of pelagic megafauna in industrial trawler fisheries off Northwest Africa. Fish Res 78:186-195. https://doi.org/10.1016/j.fishres.2006.01.012

Publisher's Note Springer Nature remains neutral with regard to jurisdictional claims in published maps and institutional affiliations. 